\title{
The paradoxes of progress
}

The paradoxes of progress have plagued architecture for most of the last century. We revitalized our cities and ended up concentrating poverty, we used technology to bring us closer to nature and ended up damaging the environment, and we established a progressive design culture and ended up isolating ourselves from the very public whose lives we sought to improve. As we begin the next century, we should ask how we might avoid the unintended consequences of our often wellmeaning efforts.

That will demand a rethinking of modernism. As the philosophers Robert Solomon and Kathleen Higgins have argued, the modern world brought 'a new emphasis on objectivity...(but) the source of the objectivity, paradoxically enough, was to be found in one's own subjectivity. Thus the modern age was founded on an apparent contradiction: we come to know the world "outside" by looking "inside."' The utopian tradition of modern architecture reflects that contradiction, as architects have asserted highly subjective visions as the basis for a universal transformation of the objective world. Whether it be the technological utopia of LeCorbusier's Plan Voisin or the Arcadian utopia of Wright's Broadacre City or the rational utopia of Burnham's Chicago Plan, architects emerged in the $20^{\text {th }}$ century at the vanguard of efforts around the globe to realize, as a universal objective fact, one person's subjective vision. And we have paid a heavy price for that hubris: not only a physical price - whether in the loss of the historic cores of our cities in realizing LeCorbusier's urban vision or in the destruction of the rural landscape in realizing Wright's suburban one - but a political price as well - in the tremendous human and environmental losses we've taken in realizing the utopias of Marx, Nietzsche, and now in the midst of global laissez-faire capitalism, Adam Smith.

As we look ahead, can we have 'progress without utopia' as Edward Rothstein asked recently in the New York Times? Can we improve the lives of all people and respect the existence of all species, without lapsing back into our old utopian ways of imposing singular subjective visions onto others? That will depend upon our finding a new relationship between the objective and subjective realms, in which they are neither totally separate nor as a matter of one dominating the other, but instead interwoven and mutually respectful realities. For architecture, that means shaping environments whose objective reality recognizes the diverse subjective realities of those who inhabit what we create, as well as seeing our own subjective reality, as architects, as just one of many inputs into the objective realities we design.

THE EDITORS 


\section{architectural research quarterly}

\section{Subscribe now for 2001}

Innovative in conception, unique in breadth and generously illustrated, this pace-setting quarterly publication from Cambridge University Press links, on a global scale, the worlds of architectural practice and research. arq regularly includes extensive peer-reviewed sections on design, history, theory, construction, environmental design, information technology and practice - as well as structures, urbanism and documents. These are supplemented by letters, reports, reviews, a directory of specialist research centers and consultancies and an annual index. Each issue opens with a leader and closes with insight, a personal end-piece. In its three year history, arq has published work from all over the world: from Chile to Sweden and from Japan to the Netherlands - with a strong representation from the United Kingdom and United States. arq, like architecture itself, is all-embracing and written by and for both practitioners and academics. It provides an outlet for all those who wish to disseminate

their work to an international audience.
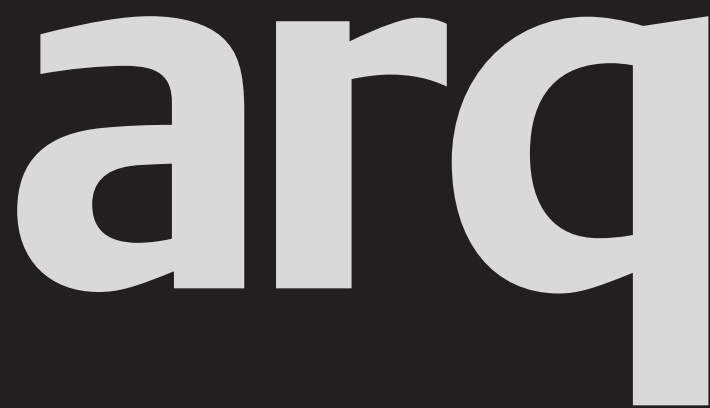

Please enter my subscription to

arq: architectural research quarterly, volume 5, 2001

$$
\begin{aligned}
& £ 98 / \$ 160 \text { institutions print only } \\
& £_{27} / \$ 44 \text { students } \\
& £ 40 / \$ 60 \text { individuals print only }
\end{aligned}
$$

EU residents only. VAT may be payable at your local rate if not registered.

Our VAT registration number: GB 214141614 If registered, your VAT registration no:

Total subscription payment $£ / \$$

EU residents only, if not registered add VAT at appropriate rate

Canadian residents, add 7\% GST \$

Total $\mathbf{E} / \mathbf{S}$

Name

Address

\section{Payment enclosed}

Cheque in sterling or US dollars

(payable to Cambridge University Press)

Credit Card - VISA | MasterCard | American Express (delete where applicable)

Card no

Expiry date

Signature

Photocopy this page and send your order to:

Journals Customer Services, Cambridge University Press, The Edinburgh Building, Cambridge, CB2 2RU, UK

T $+44(0) 1223326070$

F +44 (o) 1223315052

E journals_subscriptions@cup.cam.ac.uk

or in USA, Canada and Mexico send to:

Cambridge University Press, 40 West 2oth Street,

New York NY 10011-4211, USA

T (914) 9379600

F (914) 9374712

E journals_subscriptions@cup.org 